\title{
Use of amiodarone and digoxin specific Fab antibodies in digoxin overdosage
}

\author{
D P NICHOLLS, ^ J G MURTAGH,$\star$ D W HOLT $†$ \\ From the ${ }^{\star}$ Cardiac Unit, Belfast City Hospital, Belfast, Northern Ireland; and the †Poisons Unit, Guy's Hospital, \\ London
}

SUMMARY A 61 year old man with mild aortic stenosis and chronic depression took $12.5 \mathrm{mg}$ digoxin in a suicide attempt. Ventricular tachycardia and fibrillation were resistant to lignocaine and to phenytoin but responded to intravenous amiodarone, with restoration of pacing. Because of persistent hyperkalaemia he was also treated with Fab fragments of digoxin specific antibody, which bound most of the ingested digoxin.

It is suggested that the treatment of choice in severe digoxin poisoning is amiodarone for ventricular arrhythmias followed by pacing if necessary and the use of Fab antibody fragments if hyperkalaemia persists.

Digoxin overdosage is an infrequent but serious medical emergency, characterised by arrhythmias, hyperkalaemia, and resistance to pacing. The overall mortality is about $20 \%,{ }^{1-3}$ very high serum digoxin concentrations usually being associated with a fatal outcome. ${ }^{4-7}$ The use of Fab fragments of digoxin specific antibody to reverse toxicity has been described recently..$^{8-10}$ In addition, amiodarone may be an effective drug for controlling ventricular arrhythmias secondary to digoxin overdosage. ${ }^{11}$ We report a case of severe digoxin poisoning in which, for the first time, both methods of treatment were used.

\section{Case report}

A 61 year old man with a long history of depressive illness requiring previous inpatient care and electroconvulsive therapy received maintenance treatment with amitriptyline. In June 1983 he developed breathlessness and palpitation and was investigated by another hospital. An echocardiogram showed mild aortic stenosis, and 24 hour electrocardiographic monitoring showed sinus rhythm with occasional ventricular extrasystoles. Treatment was started with digoxin $0.25 \mathrm{mg}$ daily and the amitriptyline withdrawn. After this he became more depressed. In November 1983 he attempted suicide by taking 50 tablets of $0.25 \mathrm{mg}$ digoxin because he understood that "they would slow the heart down." One hour later no Requests for reprints to Dr J G Murtagh, Cardiac Unit, Belfast City Hospital, Lisburn Road, Belfast BT9 7AB. effect was apparent so he incised both radial arteries. The bleeding soon stopped, and he gave up his suicide attempt.

On arrival at our casualty department four hours after ingestion of the tablets he was pale but alert with no nausea. An electrocardiogram showed a PR interval of $240 \mathrm{~ms}$ with widespread ST segment depression. Haemoglobin concentration was $8 \mathrm{~g} / \mathrm{dl}$, serum potassium concentration $4.7 \mathrm{mmol} / \mathrm{l}$, and serum digoxin concentration $11 \mu \mathrm{g} / \mathrm{l}$. Shortly after admission, he developed ventricular tachycardia and fibrillation alternating with periods of asystole requiring 13 DC cardioversions despite the intravenous administration of lignocaine $100 \mathrm{mg}$ on two occasions and of phenytoin $250 \mathrm{mg}$. During insertion of a temporary transvenous pacing wire the unstable rhythm continued and required a further $36 \mathrm{DC}$ cardioversions. Figure 1 shows the rhythms recorded at this time: ventricular tachycardia, ventricular fibrillation, asystole with artefacts due to cardiac compression, and failure of pacing to capture despite maximum output (12 V).

Seven hours after ingestion of the tablets amiodarone $150 \mathrm{mg}$ was given intravenously over five minutes. An electrocardiogram at this time showed restoration of pacing capture (threshold $1.3 \mathrm{~V}$ ) and finally a regular junctional rhythm accompanied by good cardiac output (Fig. 1). A further intravenous dose of amiodarone was given (total $5 \mathrm{mg} / \mathrm{kg}$ loading dose) followed by an infusion of $900 \mathrm{mg}$ over 24 hours. 
Nine hours after ingestion of the digoxin tablets his cardiac rhythm was stable, but the serum digoxin concentration had risen to $14 \mu \mathrm{g} / \mathrm{l}$ and the serum potassium concentration to $6.8 \mathrm{mmol} / \mathrm{h}$. It was decided to treat him with Fab fragments of digoxin specific antibody, but as there was only one batch of antibody available in the United Kingdom the anti-
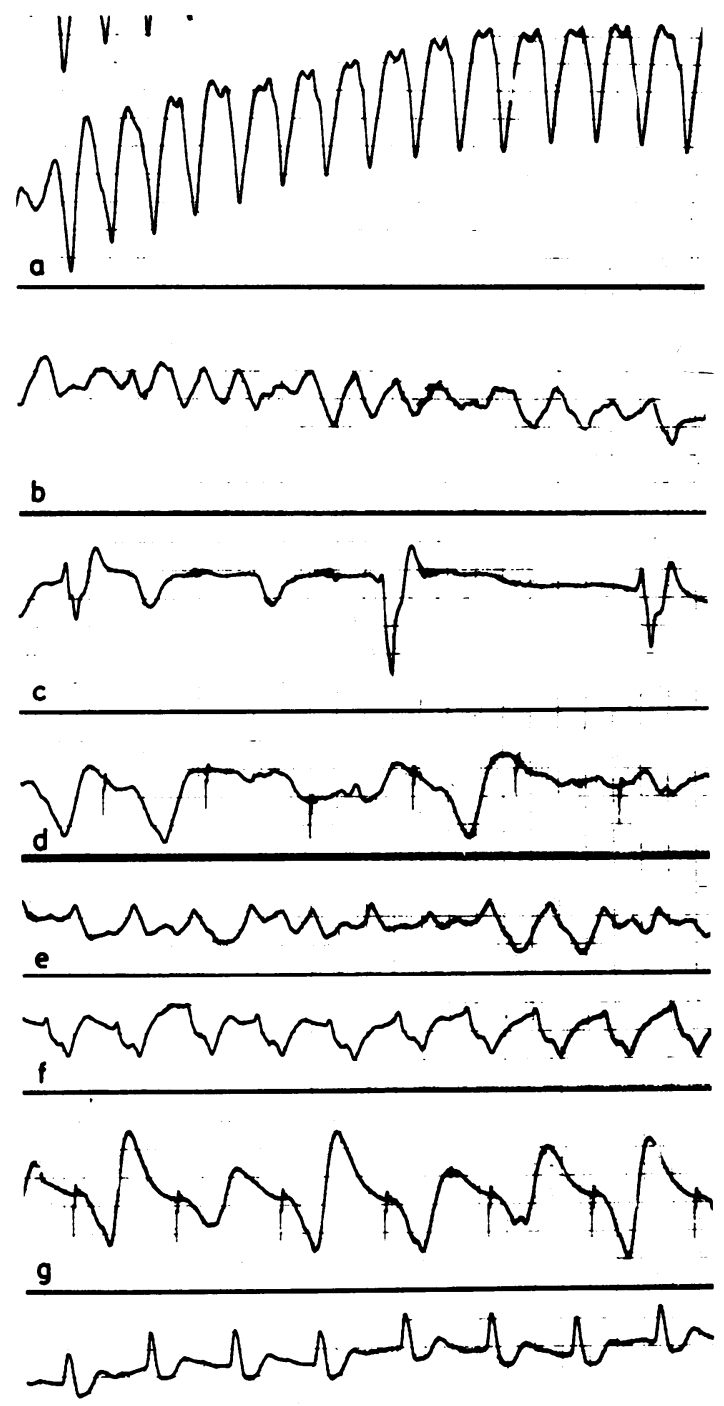

h

Fig. 1 Electrocardiogram (lead II) showing rhythms $((a)-(d))$ before and $((e)-(h))$ after the intravenous administration of amiodarone $150 \mathrm{mg}:$ (a) ventricular tachycardia; (b) ventricular fibrillation; (c) asystole with external cardiac compression; $(d)$ failure of capture of pacing despite maximum output $(12 \mathrm{~V}) ;(e)$ ventricularfibrillation at one minute; $(f)$ a regular rhythm at two minutes; (g) capture of pacing (threshold $1.3 \mathrm{~V}$ ) at three minutes; and $(h)$ a junctional rhythm at four minutes. body was not available for use unil 18 hours after ingestion of the tablets. A test dose of $2 \mathrm{mg}$ of antibody was given followed 30 minutes later by $600 \mathrm{mg}$ (60 times the amount ingested assuming $80 \%$ absorption) contained in $100 \mathrm{ml}$ of $5 \%$ dextrose and infused over 15 minutes.

Figure 2 shows the total serum digoxin concentrations measured from the time of ingestion of tablets $(0$ hours). Within 30 minutes of the administration of the test dose of antibody the total serum digoxin concentration increased 10-fold from 19 to $190 \mu \mathrm{g} / \mathrm{l}$ and the serum potassium concentration fell from 6.2 to $4.0 \mathrm{mmol} / \mathrm{l}$.

Free digoxin was not detected in plasma until 47 hours after ingestion of tablets $(2.4 \mu \mathrm{g} / \mathrm{l})$ and declined thereafter. Urine digoxin concentration was 90$640 \mu \mathrm{g} / \mathrm{l}$ in the six hours before the administration of antibody and rose to a maximum of $2470 \mu \mathrm{g} / 1$ four hours after treatment.

The patient made an uneventful recovery from his overdose and has continued to take oral amiodarone $200 \mathrm{mg}$ daily with satisfactory control of his cardiac symptoms. He was transferred for psychiatric care, treated with mianserin and psychotherapy, and is now back at work.

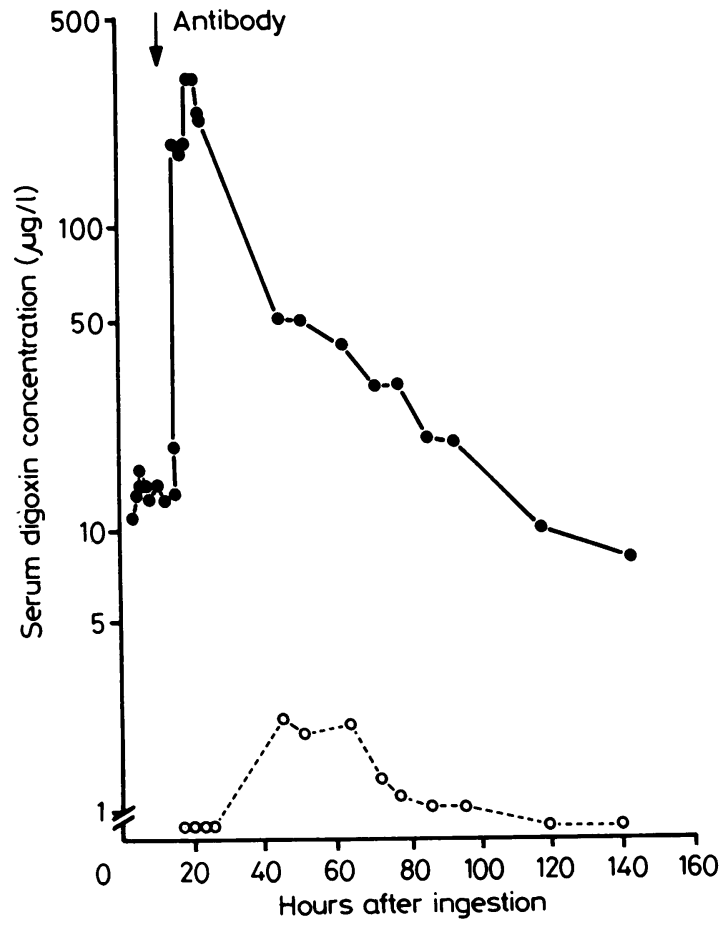

Fig. 2 Total $(\bullet)$ and free $(O)$ serum digoxin concentrations $(\mu \mathrm{g} / \mathrm{l})$ at intervals after ingestion of $12.5 \mathrm{mg}$ digoxin at 0 hours. Fab digoxin specific antibody $2 \mathrm{mg}$ was given at 18 hours and $600 \mathrm{mg}$ at 18.5 hours after drug ingestion. 
MEASUREMENT OF DIGOXIN CONCENTRATION

Plasma digoxin concentrations were measured by fluorescence polarisation immunoassay (Abbott TDx); the limit of accurate measurement for this method is $0.2 \mu \mathrm{g} / \mathrm{l}$. Free digoxin was measured after equilibrium dialysis. ${ }^{8}$ Total digoxin concentrations, after treatment with antidigoxin antibody fragments, were measured after heating the samples for one hour at $100^{\circ} \mathrm{C}$ and dilution with digoxin free heparinised human plasma. Plasma amiodarone concentrations were measured using high performance liquid chromatography. ${ }^{12}$

\section{Discussion}

The ventricular tachyarrhythmias observed after severe digoxin poisoning may be resistant to treatment. In this case, amiodarone stabilised the cardiac rhythm whereas lignocaine and phenytoin had previously been ineffective, confirming the clinical value of amiodarone in this situation. ${ }^{11}$ Control of the ventricular arrhythmias was maintained by infusion of amiodarone, which produced plasma concentrations in the range of $0.6-0.8 \mathrm{mg} / 1$. For comparison, chronic oral treatment with amiodarone $200 \mathrm{mg}$ daily produces plasma concentrations of about $1 \mathrm{mg} / 1 .{ }^{13}$ The reasons for the efficacy of amiodarone in the treatment of digoxin induced ventricular arrhythmias is not clear, but in addition to the antiarrhythmic action of amiodarone it may also displace digoxin from myocardial binding sites. ${ }^{14}$ This produces an increase in the plasma concentration of digoxin ${ }^{15}$ but may possibly reduce myocardial toxicity. It is interesting to note that in our patient amiodarone also reduced the pacing threshold.

Although amiodarone may stabilise the rhythm disturbances, there remains a large body pool of digoxin to clear. Conventional methods of treatment such as haemodialysis are ineffective because the plasma is constantly replenished from a large tissue compartment. Hyperkalaemia is a sign of severe toxicity ${ }^{34}$ as it implies failure of the myocardial membrane adenosine triphosphatase pump.1617 Although dialysis or glucose/insulin may reduce the serum potassium concentration in some cases, in others the concentration continues to increase and may cause fatal arrhythmias. For this reason, it is important to enhance the clearance of digoxin if hyperkalaemia is present. The effectiveness of digoxin specific antibody in clearing digoxin is shown in this and in the other cases reported. ${ }^{8-10}$

We suggest that the treatment of choice for severe digoxin poisoning should be intravenous amiodarone for life threatening ventricular arrhythmias followed by pacing if bradycardia is evident and the use of digoxin specific antibodies if hyperkalaemia is present.
We thank the Wellcome Foundation for supplies of antibody and Mrs Bowman and the British Red Cross Society for transporting the antibody.

\section{References}

1 Bergy GC, Fergus EB, Bruce RA. Acute massive digitoxin poisoning: report of a case and review of the literature. Ann Intern Med 1957; 46: 964-76.

2 Gaultier M, Fournier E, Efthymiou M-L, Fréjaville J-P, Jouannot $P$, Dentan $M$. Intoxication digitalique aigüe (70 observations). Bull Soc Med Hop Paris 1968; 119: 24774.

3 Bismuth C, Gaultier M, Bonnet M, Pollet J. L'hyperkaliémie dans l'intoxication digitalique massive. Biomedicine [Express] 1973; 19: 152-5.

4 Smith TW, Willerson JT. Suicidal and accidental digoxin ingestion: report of five cases with serum digoxin level correlations. Circulation 1971; 44: 29-36.

5 Reza MJ, Kovick RB, Shine KI, Pearce ML. Massive intravenous digoxin overdosage. $N$ Engl f Med 1974; 291: 777-8.

6 Bremner WF, Third JLHC, Lawrie TDV. Massive digoxin ingestion. Report of a case and review of currently available therapies. $\mathrm{Br}$ Heart $\mathcal{F}$ 1977; 39: 688-92.

7 Nicholls DP. Fatal digoxin overdose. Postgrad Med $\mathcal{F}$ 1977; 53: 280-1.

8 Smith TW, Haber E, Yeatman L, Butler VP Jr. Reversal of advanced digoxin intoxication with Fab fragments of digoxin-specific antibodies. $N$ Engl $\mathcal{F}$ Med 1976; 294: 797-800.

9 Smith TW, Butler VP Jr, Haber E, et al. Treatment of life-threatening digitalis intoxication with digoxinspecific Fab antibody fragments. Experience in 26 cases. N Engl F Med 1982; 307: 1357-62.

10 Rozkovec A, Coltart DJ. Treatment of digoxin overdose with antigen-binding fragments of digoxin-specific antibodies. $\mathrm{Br} \mathrm{Med} \mathcal{F}$ 1982; 285: 1315-6.

11 Maheswaran R, Bramble MG, Hardistry CA. Massive digoxin overdose: successful treatment with intravenous amiodarone. $\mathrm{Br}$ Med $\mathcal{F}$ 1983; 287: 392-3.

12 Flanagan RJ, Storey GCA, Holt DW. Rapid highperformance liquid chromatographic method for the measurement of amiodarone in blood-plasma or serum at the concentrations attained during therapy. $\mathcal{F}$ Chromatogr 1980; 187: 391-8.

13 Holt DW, Tucker GT, Jackson PR, Storey GCA. Amiodarone pharmacokinetics. Am Heart $\mathcal{F}$ 1983; 106: 840-7.

14 Douste-Blazy P, Monastruc JL, Bonnet B, Auriol P, Conte $D$, Bernadet $P$. Influence of amiodarone on plasma and urine digoxin concentrations [Letter]. Lancet 1984; i: 905.

15 Moysey JO, Jaggarao NSV, Grundy EN, Chamberlain DA. Amiodarone increases plasma digoxin concentrations. Br Med F 1981; 282: 272.

16 Glynn IM. The action of cardiac glycosides on ion movements. Pharmacol Rev 1964; 16: 381-407.

17 Doherty JE. Digoxin antibodies and digitalis intoxication. $N$ Engl $\mathcal{Y}$ Med 1982; 307: 1398-9. 